\title{
Estimating the Production Potential of Major Crops in Pakistan's Irrigated Agriculture during the 21st Century
}

\author{
WAQAR A. JEHANGIR, NAZIM ALI, ZAKIR HuSSAIN RANA, and ZULFIQAR A. GILL
}

\section{INTRODUCTION}

Land and irrigation are the basic resources in agriculture. The role and importance of these resources and their contribution towards productivity, in the context of the country's increasing population, can hardly be exaggerated. Pakistani agriculture is set in a very distinctive situation of an increasing population on the one hand and diminishing resources on the other. The population of Pakistan was reported to be 131.63 million in 1996 and is projected to be 207 million in 2013 [Pakistan (1996) and WSIP (1990)]. The agriculture sector has to face the difficult task of doubling the existing food production by the turn of this century. The situation demands horizontal and vertical growth in the productivity, either by bringing more land under cultivation, or by increasing the cropping intensity of the existing land resources. This can also be accomplished by bringing more land under cultivation from the cultivable uncultivated area (a large proportion of which exists on medium and large farms under waterlogged or saline conditions). In this context, it becomes important to identify the nature of the relationship that exists between farm size and unculturable wastelands and the kinds of changes the green revolution/SCARPs projects introduced to this relationship.

\section{OBJECTIVES}

The objectives of the present study are:

- To estimate the operational distribution of land holdings in the Rechna Doab across different farm size groups in terms of the percentage distribution of holdings;

Waqar A. Jehangir is Agricultural Economist, and Nazim Ali Research Assistant, in the IIMIPakistan, Zakir Hussain Rana is Cotton Commissioner in the Ministry of Food, Agriculture and Livestock, Islamabad and Zulfiqar A. Gill is Chairman, Department of Cooperation and Credit, University of Agriculture Faisalabad, respectively. 
- To determine the total unused cultivable land in the Rechna Doab and to study the relationship between the size of holding and the level of unused cultivable land;

- To study the relationship between cropping intensity and the size of holding, as well as the influence of the level of irrigation on the cropping intensity;

- To determine the level of efficiency in land utilisation for the Rechna Doab, as well as at the district level; and

- To assess the additional potential productivity of four major crops in the Rechna Doab.

\section{PHYSIOGRAPHY OF THE RECHNA DOAB}

The cultivated area in the Rechna Doab is regarded as the grainary of the Punjab Province. The area consists of two distinct agro-climatic zones, i.e. the Punjab RiceWheat (PRW) Zone and the Punjab Sugarcane-Wheat (PSW) Zone [WAPDA (1979)]. Irrigated agriculture started in the Rechna Doab in 1892 via the Lower Chenab Canal. The irrigation system in the Rechna Doab consists of $504 \mathrm{~km}$ of branch canals, $240 \mathrm{~km}$ of main canals and $373 \mathrm{~km}$ of link canals. The Rechna Doab has a gross area of 2.98 Mha, of which 2.32 Mha is the Gross Command Area. The major canal systems are:

- The M.R. Link Canal, which started in 1956 and has 0.063 Mha of Canal Command Area (CCA);

- The Upper Chenab Canal started in 1912 and has 0.413 Mha of CCA;

- The Lower Chenab Canal started in 1892 and has 1.23 Mha of CCA; and

- The Haveli Canal started in 1939 and has 0.072 MHa of CCA.

The physiography of the Rechna Doab consists of (a) active flood plains; (b) abandoned flood plains; (c) bar uplands; and (d) Kirana Hills (longitudinal across the Rechna Doab). The ground water quality in the Rechna Doab is divided into three distinct zones: (i) Fresh Water Zone (FWZ, TDS < 1000 PPM) 1.36 Mha; (ii) Mixing Zone (MZ, TDS 1000-3000 PPM) 1.42 Mha; and (iii) Saline Water Zone (SWZ, TDS > 3000 PPM) 0.198 Mha [IWASRI (1988)]. The soils are tertiary in nature and have recent alluvial deposits, which have proportions of fine to very fine sand and silt. Soils are southwesterly sloped at $0.38 \mathrm{~m} / \mathrm{km}$ and $0.29 \mathrm{~m} / \mathrm{km}$ in the upper and lower parts, respectively. Surface salinity is found in patches covering more than 20 percent of the cultivated area in the Rechna Doab (0.47 Mha).

\section{DATA SOURCE}

Primary and secondary data sets have been used to carry out the present study. The primary data set comprised the survey data of 443 sample farms. IIMI conducted this survey during 1995 and the sample areas were identified through the use of spatial 
models. These sample sites were located in six districts (Sheikhupura, Hafizabad, Faisalabad, T.T. Singh, Jhang and part of the Kabirwala Sub-district of the Khanewal District). The primary data were collected on a well-designed pre-tested questionnaire from farms located in 144 different sampling sites.

The district-wise temporal data and cross-section data used in the study are taken from the Agricultural Census Reports of Pakistan for the years 1960, 1972, 1980 and 1990 [Pakistan Agricultural Census Organisation (1963, 1975, 1983 and 1994)]. One advantage of this data set is that not only does it cover the pre-Green Revolution/preSCARPs period (1960), but also the Green Revolution/SCARPs period (1972), postGreen Revolution/post-SCARPs period (1980) and the matured Green Revolution/ SCARPs transition period (1990).

\section{LAND USE INTENSITY}

Since 1960, agriculture in the Rechna Doab has undergone major structural changes due to the introduction of new technologies and large investments in water development. Part of the enhanced water availability contributed to the increase in both, the cropping intensity and crop yields, while part was used to bring more land under cultivation. The 1990 census data reveals that despite all efforts to increase the cultivated area in the Rechna Doab, the total cultivated area amounted to 2.3 Mha out of 2.45 Mha. 0.05 Mha of land on agricultural farms, which is cultivable but not been brought into cultivation and classified as cultureable wastelands, still exists. Since the cultivated areas are approaching their limits in cropping intensity, the opportunity to increase the agricultural production in the country by bringing the cultivable uncultivated areas under agriculture also exists. Tables 1 and 2 provide figures pertaining to the total number of farm holdings, farm sizes and culturable wastelands, which provide insights regarding the pattern of agricultural land use and its distribution in the Rechna Doab. Of 2.45 Mha of total farm area in the Rechna Doab, 15.26 percent is located in the Faisalabad District and the remainder is distributed at 8.88 percent in Toba Tek Singh, 25.08 percent in Jhang, 17.46 percent in Gujranwala, 16.69 percent in Sialkot and 16.63 percent in the Sheikhupura Districts. Regarding the size-wise distribution at the Rechna Doab level, these tables show that small and medium farms with a larger number of farm holdings, have a smaller percentage of total farm area, while a smaller percentage of large farms have more than 27 percent of the farm area. A similar trend exists in the distribution of land among farm categories at the district level (Table 1).

Examination of Tables 1 and 2 also reveals that during the census year of 1990, about 4 percent of the total agricultural farm area were not used at all and kept as culturable wastelands. The distribution of cultivated lands and the cultivable uncultivated lands (culturable waste area) are shown in Table 2, which reflects a similar distribution trend to that of the total farm size. In other words, the highest percentage of 
cultivated area is located in Jhang (24.51 percent), followed by Gujranwala (17.28 percent), Sialkot (17.13 percent), Sheikhupura (16.79 percent), Faisalabad (15.44 percent), and Toba Tek Singh (8.85 percent). Whereas, for the distribution of culturable waste area, Table 2 shows that more than one-half (56.24 percent) of the total culturable waste area is located in the Faisalabad, Toba Tek Singh and Jhang Districts. In the Faisalabad, Toba Tek Singh, Jhang, Gujranwala, Sialkot and Sheikhupura Districts, the proportionate share of culturable waste area is reported to be 17.11 percent, 14.20 percent, 24.93 percent, 17.85 percent, 7.52 percent and 18.39 percent, respectively. Looking at the size-wise distribution at the Rechna Doab level, the smallest proportion of culturable waste area is on small farms, while the highest proportion is on large farms. This trend is similar at both, the Rechna Doab and district levels.

Table 1

Percentage Distribution of Total Farm Holdings and Total Farm Area across Farm Size Groups and Districts in the Rechna Doab, 1990

\begin{tabular}{|c|c|c|c|c|c|}
\hline \multirow[b]{2}{*}{ Districts } & \multicolumn{3}{|c|}{ Class of Total Holding } & \multirow{2}{*}{$\begin{array}{l}\text { All Groups } \\
\text { Total } \\
\text { (Hectare) }\end{array}$} & \multirow{2}{*}{$\begin{array}{c}\text { Percentage } \\
\text { Distribution Across } \\
\text { Distt. }\end{array}$} \\
\hline & $\begin{array}{c}\text { Small } \\
(\%)\end{array}$ & $\begin{array}{c}\text { Medium } \\
\text { (\%) }\end{array}$ & $\begin{array}{l}\text { Large } \\
(\%)\end{array}$ & & \\
\hline \multirow[t]{2}{*}{ Faisalabad } & 52.48 & 44.77 & 2.75 & 56791 & 18.66 \\
\hline & (19.26) & $(63.18)$ & $(17.56)$ & 374295 & $(15.26)$ \\
\hline \multirow[t]{2}{*}{ T.T.Singh } & 42.48 & 52.72 & 4.8 & 27382 & 9 \\
\hline & (13.43) & $(63.79)$ & $(22.78)$ & 217759 & (8.88) \\
\hline \multirow[t]{2}{*}{ Jhang } & 34.45 & 58.12 & 7.43 & 58189 & 19.12 \\
\hline & $(8.31)$ & $(57.25)$ & (34.44) & 615069 & (25.08) \\
\hline \multirow[t]{2}{*}{ Gujranwala } & 38.14 & 53.98 & 7.88 & 41606 & 13.67 \\
\hline & (9.38) & (52.82) & (37.8) & 428254 & $(17.46)$ \\
\hline \multirow[t]{2}{*}{ Sialkot } & 60.32 & 37.47 & 2.22 & 71769 & 23.58 \\
\hline & (23.07) & $(60.06)$ & $(16.87)$ & 409364 & (16.69) \\
\hline \multirow[t]{2}{*}{ Sheikhupura } & 43.74 & 50.53 & 5.73 & 48651 & 15.98 \\
\hline & (12.79) & $(57.54)$ & (29.67) & 407964 & $(16.63)$ \\
\hline \multirow[t]{2}{*}{ Rechna Doab } & 46.62 & 48.5 & 4.88 & 304388 & 100 \\
\hline & (13.83) & $(58.48)$ & $(27.69)$ & 2452704 & $(100)$ \\
\hline
\end{tabular}


Table 2

Percentage Distribution of Operational Farm Area and Culturable Waste Area across Farm Size Groups and Districts in the Rechna Doab, 1990

\begin{tabular}{|c|c|c|c|c|c|}
\hline \multirow[b]{2}{*}{ Districts } & \multicolumn{3}{|c|}{ Size Class of Total Holding } & \multirow{2}{*}{$\begin{array}{l}\text { All Groups } \\
\text { Total } \\
\text { Hectare }\end{array}$} & \multirow{2}{*}{$\begin{array}{c}\text { Percentage } \\
\text { Distribution Across } \\
\text { Rechna }\end{array}$} \\
\hline & $\begin{array}{l}\text { Small } \\
(\%)\end{array}$ & $\begin{array}{c}\text { Medium } \\
\text { (\%) }\end{array}$ & $\begin{array}{c}\text { Large } \\
(\%)\end{array}$ & & \\
\hline Faisalabad & $\begin{array}{c}19.67 \\
(12.18)\end{array}$ & $\begin{array}{c}63.47 \\
(60.26)\end{array}$ & $\begin{array}{c}16.87 \\
(27.55)\end{array}$ & $\begin{array}{l}355991 \\
(14662)\end{array}$ & $\begin{array}{c}15.44 \\
(17.11)\end{array}$ \\
\hline T.T.Singh & $\begin{array}{l}13.99 \\
(5.05)\end{array}$ & $\begin{array}{c}64.2 \\
(57.02)\end{array}$ & $\begin{array}{c}21.8 \\
(37.93)\end{array}$ & $\begin{array}{l}204070 \\
(12168)\end{array}$ & $\begin{array}{c}8.85 \\
(14.2)\end{array}$ \\
\hline Jhang & $\begin{array}{c}8.66 \\
(3.88)\end{array}$ & $\begin{array}{c}59.05 \\
(36.33)\end{array}$ & $\begin{array}{c}32.28 \\
(59.79)\end{array}$ & $\begin{array}{l}565228 \\
(21362)\end{array}$ & $\begin{array}{c}24.51 \\
(24.93)\end{array}$ \\
\hline Gujranwala & $\begin{array}{l}9.95 \\
(2.2)\end{array}$ & $\begin{array}{c}54.89 \\
(32.26)\end{array}$ & $\begin{array}{c}35.16 \\
(65.54)\end{array}$ & $\begin{array}{l}398565 \\
(15297)\end{array}$ & $\begin{array}{c}17.28 \\
(17.85)\end{array}$ \\
\hline Sialkot & $\begin{array}{l}23.61 \\
(8.41)\end{array}$ & $\begin{array}{c}58.49 \\
(45.96)\end{array}$ & $\begin{array}{c}15.23 \\
(45.63)\end{array}$ & $\begin{array}{c}395055 \\
(6447)\end{array}$ & $\begin{array}{l}17.13 \\
(7.52)\end{array}$ \\
\hline Sheikhupura & $\begin{array}{l}13.04 \\
(7.35)\end{array}$ & $\begin{array}{l}58.08 \\
(48.2)\end{array}$ & $\begin{array}{c}28.87 \\
(44.45)\end{array}$ & $\begin{array}{l}387292 \\
(15759)\end{array}$ & $\begin{array}{c}16.79 \\
(18.39)\end{array}$ \\
\hline Rechna Doab & $\begin{array}{l}14.35 \\
(6.15)\end{array}$ & $\begin{array}{c}59.58 \\
(45.54)\end{array}$ & $\begin{array}{c}26.07 \\
(48.31)\end{array}$ & $\begin{array}{c}2306201 \\
(85695)\end{array}$ & $\begin{array}{c}100 \\
-100\end{array}$ \\
\hline
\end{tabular}

Note: Figures in parenthesis indicate the distribution of Culturable Waste Area (CWA), and those without parenthesis the distribution of operational farm area (CAT).

The impression gauged from examining these gross numbers is that as the farm size increases, the area under cultivable uncultivated land also increases. To test the statistical relationship between the farm size and culturable waste area, this study investigates the distribution of the total unused cultivable land in the Rechna Doab, and its relationship with the size of the holding and the level of unused cultivable land by using the dis-aggregated district data.

\section{SPECIFICATION OF THE MODEL}

Two aspects of the problem of under-utilisation of lands are mentioned earlier, viz., the proportion of cultivable area actually cultivated and how intensively the 
cultivated area is cropped in one year. Also, a multiplicative relationship is assumed and the econometric criteria suggested by Fuss, Mcfadden and Mundlak (1978), Madala (1988) and Ramunathan (1992) are used. The log-linear models were the best match to test the relationship between farm size, proportion of irrigation and their effects after the green revolution/SCARPs on culturable waste areas and cropping intensity. The dependent and independent variables, which are included in the models, are defined in the following:

$$
\begin{aligned}
& \ln C W A=\ln a+\ln D_{72}+\ln D_{80}+\ln D_{90}+B_{1} \ln F A T+B_{2} \ln F A T_{72} \\
& +B_{3} \ln F A T_{80}+B_{4} \ln F A T_{90}+\text { e. } \quad \ldots \quad \ldots \quad \ldots \quad \ldots \quad \ldots \\
& \ln C W A=\ln a+\ln D_{72}+\ln D_{80}+\ln D_{90}+B_{1} \ln F A T+B_{2} \ln F A T_{72} \\
& +B_{3} \ln F A T_{80}+B_{4} \ln F A T_{90}+B_{5} \ln (C A I / F A T)+ \\
& B_{6} \ln (C A I / F A T)_{72}+B_{7} \ln (C A I / F A T)_{80}+B_{8} \ln (C A I / F A T)_{90}+e_{\ldots} \ldots(2) \\
& \ln C I=\ln a+\ln D_{72}+\ln D_{80}+\ln D_{90}+B_{1} \ln F A T+B_{2} \ln F A T_{72} \\
& +B_{3} \ln F A T_{80}+B_{4} \ln F A T_{90}+\text { e. } \quad \ldots \quad \ldots \quad \ldots \quad \ldots \quad \ldots \quad \ldots \quad(3) \\
& \ln C I=\ln a+\ln D_{72}+\ln D_{80}+\ln D_{90}+B_{1} \ln F A T+B_{2} \ln F A T_{72} \\
& +B_{3} \ln F A T_{80}+B_{4} \ln F A T_{90}+B_{5} \ln (C A I / F A T) \\
& +B_{6} \ln (C A I / F A T)_{72}+B_{7} \ln (C A I / F A T)_{80}+B_{8} \ln (C A I / F A T)_{90}+e . \ldots
\end{aligned}
$$

Where:

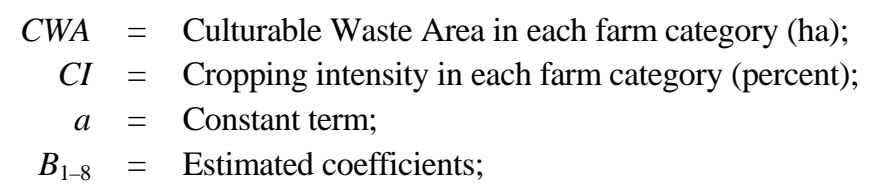

$D_{72-90}=$ Intercept dummies for the years 1972, 1980 and 1990, respectively;

$F A T=$ Average size of holding per farm in each farm category (ha);

$F A T_{72}=1972$ dummy for average size of holding per farm on each farm category (ha);

$F A T_{80}=1980$ dummy for average size of holding per farm on each farm category (ha);

$F A T_{90}=1990$ dummy for average size of holding per farm on each farm category (ha);

$($ CAI/FAT $)=$ Proportion of irrigated area per farm on each farm category (percent);

$(\text { CAI/FAT })_{72}=1972$ dummy for proportion of irrigated area per farm on each farm category (percent);

$(\text { CAI/FAT })_{80}=1980$ dummy for proportion of irrigated area per farm on each farm category (percentage); 
$(C A I / F A T)_{90}=1990$ dummy for proportion of irrigated area per farm on each farm category (percent); and

$e=$ Random error term.

According to Equation 1, if the proportion of culturable wasteland increases with the holding size then the value of the beta coefficient $\left(B_{1}\right)$ will be greater than one. This means that as the farm size increases, the amount of culturable waste area $(C W A)$ will increase in excess of proportions prior to the Green Revolution/SCARP projects. In order to find the temporal changes in this relationship from the 1960s to 1990, slope coefficients for $F A T_{72,} F A T_{80}$ and $F A T_{90}$ are summed up $\left(B_{1}+B_{2}, B_{1}+B_{3}, B_{1}+B_{4}\right)$. This is used to determine whether this relationship is strengthened or weakened by whether the sum is greater than, or less than, $B_{1}$, respectively). To determine how the increase in proportionate area under irrigation affects the CWA, Equation 2 was estimated. The temporal changes in proportionate area under irrigation on the farms is represented by CAI/FAT, $(C A I / F A T)_{72},(C A I / F A T)_{80}$ and $(C A I / F A T)_{90}$, respectively, from the 1960s to 1990. A negative relationship between the increase in proportionate area under irrigation and the effect of irrigation on CWA is anticipated. The intercept term will capture the impact of the technological development. A negative relationship between technological development and CWA is expected. The equations in Models 3 and 4 were estimated to study the relationship between the cropping intensity $(C I)$ and other variables, such as the farm size and level of irrigation, both before, during and after the Green Revolution/SCARPs projects. The results are reported in the following section. A negative relationship is expected between the farm size and $C I$ and a positive relationship between the proportionate area under irrigation and the $C I$. The technological development should lead to an increase in the $C I$ and a positive sign for the intercept term is expected. The intercept dummies will provide information about the temporal changes in the impact of technological development on the CWA and CI.

\section{CULTIVABLE UNCULTIVATED LAND AND ITS RELATION TO FARM SIZE AND IRRIGATION}

The regression results derived through Models 1 and 2, specified in the earlier section, are summarised in Table 3. Model 1 captures the effect of the farm size on the CWA. In order to study the effect of the increase in the proportionate irrigation supply along with the farm size on the culturable waste area, the parameters in Model 2 were estimated. The results show that both regression equations for the Rechna Doab has high explanatory power and the expected signs and magnitude for the estimated parameters. The explanatory power $\left(R^{2}\right)$ is 0.7529 and 0.7543 for Models 1 and 2, respectively. Both equations in Models 1 and 2 are statistically significant at the 99 percent level of confidence. The examination of Table 3 confirms that the postulated 
Table 3

Culturable Waste Area with Respect to Farm Area and Proportionate Irrigated Area in the Rechna Doab, 1990

\begin{tabular}{lcc}
\hline Variables & CWA & CWA \\
\hline Constant & $-0.4900^{* * *}$ & $-3.3313^{* * *}$ \\
& $(0.0159)$ & $(0.7024)$ \\
DV72 & $-6.2293^{* * *}$ & $\mathrm{~N} . \mathrm{S}$ \\
& $(1.6111)$ & $\mathrm{N} . \mathrm{S}$. \\
DV80 & $-3.6920^{* *}$ & \\
& $(1.5985)$ & $-0.9014^{* * *}$ \\
DV90 & $-4.8951^{* * *}$ & $(0.2200)$ \\
& $(1.6229)$ & $1.0439^{* * *}$ \\
FAT & $0.8259^{* * *}$ & $(0.0584)$ \\
& $(0.1065)$ & $0.2154^{*}$ \\
FAT72 & $0.4429^{* * *}$ & $(0.1103)$ \\
& $(0.1422)$ & $\mathrm{N} . \mathrm{S}$. \\
FAT80 & $0.2398^{*}$ & \\
& $(0.1414)$ & $\mathrm{N} . \mathrm{S}$. \\
FAT90 & $0.331482^{* *}$ & \\
& $(0.1440)$ & $-0.7640^{* * *}$ \\
CAIFAT & & $(0.2539)$ \\
& & $\mathrm{N} . \mathrm{S}$ \\
CAIFAT72 & & $\mathrm{N} . \mathrm{S}$. \\
CAIFAT80 & $\mathrm{N} . \mathrm{S}$. \\
CAIFAT90 & & 95.7013 \\
F-CALC & 179 \\
D.F. & 179 & 0.7543 \\
ADJ-R2 & 0.7529 & \\
\hline
\end{tabular}

Note: Figures in parentheses are standard error.

* Significant at 90 percent level of confidence.

** Significant at 95 percent level of confidence.

*** Significant at 99 percent level of confidence.

N.S. $=$ Not significant at 90 percent level of confidence.

relationship between the farm size and culturable wastelands is empirically valid for all four periods (before, during and after the Green Revolution/SCARPs). Surprisingly, ten years after the Green Revolution, during the 1990s, the Rechna Doab CWA has increased as the coefficient for $F A T_{90}$ is positive, higher than $F A T_{80}$ and statistically significant at the 99 percent level of confidence. One reason might be that the secondary salinisation (due to the exploitation of the poor quality ground water through SCARP 
tubewells) led to this increase in the cultureable waste area during the 1990s. The intercept term and intercept dummies have negative signs and the coefficients are significant (at the 99 percent level of confidence) for 1972, 1980 and 1990, which confirms that the technological development led to a decrease in the CWA. In the case of Model 2, the relationship between the farm size and CWA remains the same during the 1980s and 1990s as for 1972, because the coefficient for $F A T_{80}$ and $F A T_{90}$ is insignificant.

For the partial effect of irrigation on CWA in Model 2, it has been found that irrigation played a significant role in reducing the CWA in the 1960s (as the elasticity coefficient for irrigation is negative and significant at the 99 percent level of confidence). In the period after the 1960s, there was not much improvement in the proportionate area under irrigation, which could play a significant role in decreasing CWA.

\section{CROPPING INTENSITY AND ITS RELATION TO FARM SIZE AND IRRIGATION}

The existence of a negative relationship between farm size was expected. In order to test this relationship, Model 3, with a cropping intensity as the dependent variable and the farm size and their post-1970s dummies as the explanatory variables, were tested in the equations. The regression coefficient estimates of Model 3 are summarised in Table 4. All the coefficients have the expected size and sign, proving the argument of an inverse relationship between farm size and cropping intensity, as they are significant at the 99 percent level of confidence. The explanatory power of the Model $\left(\mathrm{R}^{2}\right)$ is 0.6312 and 0.6557 for Models 3 and 4, respectively. Clear from the equation for Model 3 is that the greater the farm size, the lower the cropping intensity. This inverse relationship is significant at the 99 percent level of confidence during 1972, 1980 and 1990. This relationship persists during, as well as after, the Green Revolution period.

After examining the relationships between farm size and cropping intensity, it was thought that the irrigation level could possibly be an important factor affecting cropping intensity. In order to test this relationship, Model 4 was estimated by incorporating the proportionate area under irrigation per farm, along with the farm size and intercept dummies. The summary of results from Model 4 is also given in Table 4 . That the intercept is positive and all the FAT coefficients after the 1970s are significant at the 99 percent level of confidence and have a negative sign, showing the negative relation between farm size and cropping intensity is shown. Regarding the effect of irrigation on cropping intensity, it is positive and significant at the 99 percent level of confidence during the 1980s. This means that if sufficient irrigation was made available, then many culturable areas exist, but are in need this irrigation to assure the returns to 
Table 4

Cropping Intensity with Respect to Farm Area and Proportionate Irrigated Area in the Rechna Doab, 1990

\begin{tabular}{|c|c|c|}
\hline Variables & $\mathrm{CI}$ & $\mathrm{CI}$ \\
\hline \multirow[t]{2}{*}{ Constant } & $4.6995 * * *$ & $4.6939 * * *$ \\
\hline & $(0.0158)$ & $(0.0155)$ \\
\hline \multirow[t]{2}{*}{ DV72 } & $0.6699 * * *$ & $0.6755^{* * *}$ \\
\hline & $(0.1088)$ & $(0.1054)$ \\
\hline \multirow[t]{2}{*}{ DV80 } & $0.7219 * * *$ & $0.7636 * * *$ \\
\hline & $(0.1147)$ & $(0.1121)$ \\
\hline \multirow[t]{2}{*}{ DV90 } & $0.6315^{* * *}$ & $0.6247 * * *$ \\
\hline & $(0.1134)$ & $(0.1101)$ \\
\hline \multicolumn{3}{|l|}{ FAT } \\
\hline \multirow[t]{2}{*}{ FAT72 } & $-0.0447 * * *$ & $-0.0447 * * *$ \\
\hline & $(0.0095)$ & -0.0092 \\
\hline \multirow[t]{2}{*}{ FAT80 } & $-0.0412^{* * *}$ & $-0.0420 * * *$ \\
\hline & $(0.0100)$ & $(0.0097)$ \\
\hline \multirow[t]{2}{*}{ FAT90 } & $-0.0256 * *$ & $-0.02199 * *$ \\
\hline & $(0.0100)$ & $(0.0099)$ \\
\hline CAIFAT & & N.S. \\
\hline CAIFAT72 & & N.S. \\
\hline \multirow[t]{2}{*}{ CAIFAT80 } & & $0.1372^{* *}$ \\
\hline & & $(0.0562)$ \\
\hline CAIFAT90 & & 0.2015 \\
\hline$\overline{\text { F-CALC }}$ & $54.6251^{* * *}$ & $45.5198^{* * *}$ \\
\hline D.F. & 182 & 179 \\
\hline ADJ-R2 & 0.63119 & 0.6557 \\
\hline
\end{tabular}

Note: Figures in parentheses are standard error.

* Significant at 90 percent level of confidence.

** Significant at 95 percent level of confidence.

*** Significant at 99 percent level of confidence.

N.S. $=$ Not significant at 90 percent level of confidence. 
investment in those areas. If irrigation can be brought to these areas, they will have a tendency to bring more area under cultivation, and thereby, reduce the unculturable waste areas.

The above discussion confirms that small farmers crop their lands more intensively than large farmers, and that this trend persists even after the Green Revolution. This does not mean that the actual cropping intensity has gone down, but rather, in comparison to large farms, small farms grow crops on their lands more efficiently.

\section{CROPPING INTENSITY AND LEVELS OF INEFFICIENCY OF LAND USE}

The results from Tables 1 and 2 showed that both, intensive and extensive use of land is lower on large farms when compared to small farms. In other words, as the farm size increases both, intensive and extensive use of land decreases. So what happens if everybody uses the land the way the small farmers are using it? Or what if land is redistributed? Whatever policy is implemented to fully utilise the land, at least the unirrigated area will be cultivated once and the irrigated area cultivated twice. If such a policy is followed, then how much inefficiency exists in extensive and intensive farming at the aggregate and the district levels? On the basis of these assumptions, some indices have been developed (indicated in Tables 5-9). These indices will help to establish the amount land that is underutilised, and then, how it is distributed among different farm categories in different regions. In order to estimate the index of inefficiency, certain assumptions had to be considered reasonable within the limitations of the available data. For measuring the inefficiency in cropping intensity, irrigated areas (CAI) are assumed to have the potential for two crops, and un-irrigated areas (NSA) for at least one crop. As such, the minimum potential number of times a unit area of land is croppable (GCA) is equal to twice the net-irrigated area added to the unirrigated area. A possibility that a negative number may occur in certain cases exists, because the un-irrigated area may be cropped more than once and/or the irrigated areas may be cropped more than two times a year, thereby making the GCA greater than the sum of NSA and CAI. The lower the index number, the lower is the inefficiency.

Table 5 shows that at the Rechna Doab level, the measure of inefficiency varies from 12.66 percent for small farms, 19.64 for medium farms, and 22.58 percent for the large farms, implying that large and medium farms are less in their efficiency. From the measures of inefficiency, it is observed that the cropping intensities of the net cultivated area can be improved. The additional area, which can be cropped through intensified cropping, is given in Table 6. At the aggregate level, the additional croppable land through the improvement in cropping intensity was determined to be about 2.1 million acres. The district-wise distribution of this land across farm-size groups is computed in 
Table 5

Measures of Inefficiency in Cropping Intensity of the Net Cultivated Area across Farm Size Groups and Districts in the Rechna Doab, 1990*

\begin{tabular}{lcccc}
\hline & \multicolumn{3}{c}{ Size Class of Total Holding } & All Groups \\
\cline { 2 - 5 } Districts & Small (\%) & Medium (\%) & Large (\%) & Total (\%) \\
\hline Faisalabad & 22.44 & 29.13 & 29.69 & 27.9 \\
T.T.Singh & 20.23 & 24.87 & 27.3 & 24.74 \\
Jhang & 18.51 & 27.8 & 31.93 & 28.26 \\
Gujranwala & 7.17 & 10.84 & 14.1 & 11.61 \\
Sialkot & -0.3 & 5.89 & 13.51 & 6.18 \\
Sheikhupura & 14.43 & 16.12 & 17.42 & 16.27 \\
Rechna Doab & 12.66 & 19.64 & 22.58 & 19.47 \\
\hline
\end{tabular}

${ }^{*}$ (NSA + CAI - GCA $) * 100$.

NSA + CAI

Table 6

Percentage Distribution of Additional Croppable Land* through Improvement in Cropping Intensity across Farm Size Groups and Districts in the Rechna Doab

\begin{tabular}{|c|c|c|c|c|c|}
\hline \multirow[b]{2}{*}{ Districts } & \multicolumn{3}{|c|}{ Size Class of Total Holding } & \multirow{2}{*}{$\begin{array}{c}\text { All Groups } \\
\text { Total } \\
\text { (Hectare) }\end{array}$} & \multirow{2}{*}{$\begin{array}{c}\text { All Groups Percentage } \\
\text { Distribution } \\
\text { Across Distt. }\end{array}$} \\
\hline & $\begin{array}{c}\text { Small } \\
(\%)\end{array}$ & $\begin{array}{c}\text { Medium } \\
\text { (\%) }\end{array}$ & $\begin{array}{c}\text { Large } \\
(\%)\end{array}$ & & \\
\hline Faisalabad & 15.94 & 66.25 & 17.82 & 195928 & 22.97 \\
\hline T.T.Singh & 11.59 & 64.42 & 23.98 & 98896 & 11.6 \\
\hline Jhang & 5.92 & 58.64 & 35.44 & 303099 & 35.54 \\
\hline Gujranwala & 6.19 & 51.34 & 42.48 & 90617 & 10.63 \\
\hline Sialkot & -1.17 & 56.3 & 35.1 & 41457 & 4.86 \\
\hline Sheikhupura & 11.78 & 57.8 & 30.42 & 122817 & 14.4 \\
\hline Rechna Doab & 9.41 & 60.05 & 30.07 & 852814 & 100 \\
\hline
\end{tabular}


Table 6. The major contribution comes from the medium and large holdings of the Faisalabad, Jhang, Sheikhupura, Toba Tek Singh, Sialkot and Gujranwala Districts.

The indices to measure the inefficiency in total land use were computed by combining the inefficiency in cropping intensity with the lands, which are currently culturable waste areas (CWAs). These indices have been computed at the Rechna Doab and district levels by incorporating the CWA into the above indices' inefficiency in cropping intensity. The district level and the Rechna Doab level indices are reported in Table 7. These indices show similar trends in the distribution of inefficiency in total land use among different farm categories, as are reported in Table 5 for the measures of inefficiency in cropping intensity of the net cultivated area. Table 8 shows the indices computed to determine the percentage of

Table 7

Measures of Inefficiency in Total Land Use, Farm Size-wise for the Rechna Doab and Districts, 1990

\begin{tabular}{lcccc}
\hline & \multicolumn{3}{c}{ Size Class of Total Holding } & All \\
\cline { 2 - 4 } Districts & $\begin{array}{c}\text { Small } \\
(\%)\end{array}$ & $\begin{array}{c}\text { Medium } \\
(\%)\end{array}$ & $\begin{array}{c}\text { Large } \\
(\%)\end{array}$ & $\begin{array}{c}\text { Groups } \\
\text { Total (\%) }\end{array}$ \\
\hline Faisalabad & 23.42 & 30.51 & 32.03 & 29.37 \\
T.T.Singh & 21.08 & 26.85 & 30.96 & 26.96 \\
Jhang & 19.2 & 28.67 & 34.42 & 29.66 \\
Gujranwala & 7.57 & 11.86 & 17.14 & 13.31 \\
Sialkot & 0.04 & 6.59 & 15.81 & 7.07 \\
Sheikhupura & 15.41 & 17.54 & 20.04 & 17.98 \\
Rechna Doab & 13.38 & 20.83 & 25.3 & 21.01 \\
\hline
\end{tabular}

$*(\mathrm{NSA}+\mathrm{CAI}+\mathrm{CWA}-\mathrm{GCA}) * 100$.

$\mathrm{NSA}+\mathrm{CAI}+\mathrm{CWA}$.

Table 8

Percentage Distribution of Additional Croppable Land ${ }^{*}$ through Improvement in Culturable Waste Area across Farm Size Groups and Districts in the Rechna Doab

\begin{tabular}{|c|c|c|c|c|c|}
\hline \multirow[b]{2}{*}{ Districts } & \multicolumn{3}{|c|}{ Size Class of Total Holding } & \multirow{2}{*}{$\begin{array}{l}\text { All Groups } \\
\text { Total } \\
\text { (Hectare) }\end{array}$} & \multirow{2}{*}{$\begin{array}{c}\text { All Groups Percentage } \\
\text { Distribution } \\
\text { Across Distt. }\end{array}$} \\
\hline & $\begin{array}{c}\text { Small } \\
(\%)\end{array}$ & $\begin{array}{c}\text { Medium } \\
(\%)\end{array}$ & $\begin{array}{c}\text { Large } \\
(\%)\end{array}$ & & \\
\hline Faisalabad & 15.67 & 65.83 & 18.49 & 210590 & 22.44 \\
\hline T.T.Singh & 10.88 & 63.61 & 25.51 & 111064 & 11.83 \\
\hline Jhang & 5.79 & 57.17 & 37.04 & 324461 & 34.57 \\
\hline Gujranwala & 5.61 & 48.58 & 45.81 & 105915 & 11.29 \\
\hline Sialkot & 0.12 & 54.91 & 36.52 & 47904 & 5.1 \\
\hline Sheikhupura & 11.27 & 56.71 & 32.02 & 138576 & 14.77 \\
\hline Rechna Doab & 9.51 & 58.75 & 31.74 & 938509 & 100 \\
\hline
\end{tabular}

*NSA + CAI + CWA - GCA. 
distribution of additional croppable land through improvement in culturable waste areas at the Rechna Doab and district levels. On the Rechna Doab level, about 2.319 million acres of additional land can be brought under the croppable area through improvement in the culturable waste areas. Again, the major contributors are the medium and large farms of the Faisalabad, Toba Tek Singh and Jhang Districts.

By using the above measures of inefficiency, the total land loss is computed at the Rechna Doab and district levels (Table 9). The total increase in cropped area at the Rechna Doab level, by making improvements in cropping intensity and by including the additional area from culturable waste lands, amounts to 2.319 million acres, which is about 40.69 percent of the total croppable area. Regarding this total additional croppable land, 21.01 percent is from improvements in cropping intensity and the remainder from bringing unculturable wastelands into cultivation. By looking at Table 9, in the Faisalabad, Toba Tek Singh and Jhang Districts, the croppable areas can be developed significantly, simply through improvements in cropping intensity. The trend is similar for the Gujranwala, Sheikhupura and Sialkot Districts.

Table 9

\begin{tabular}{|c|c|c|c|c|c|}
\hline \multirow[b]{7}{*}{ Districts } & \multirow{7}{*}{$\begin{array}{l}\text { Increase in } \\
\text { Cropped Area by } \\
\text { Reclaiming and } \\
\text { Bringing under } \\
\text { Cultivation } \\
\text { Currently } \\
\text { Unused Land }\end{array}$} & \multicolumn{4}{|l|}{ Increase in } \\
\hline & & Cropped Area by & Total & Increase in CA & \\
\hline & & Improving & Increase in & by Improving & \\
\hline & & Cropping & Cropped & CI of CCA as & \\
\hline & & Intensity of & Area & $\%$ of TICA & Col.4 as \% of \\
\hline & & Currently & $(\mathrm{Col} .2) /$ & (Col. 3) / & Total Cropped \\
\hline & & Cultivated Land & (Col. 3). & $($ Col. 4)*100 & Area** \\
\hline (1) & (2) & (3) & (4) & (5) & (6) \\
\hline Faisalabad & 14662 & 195928 & 210590 & 93.04 & 29.37 \\
\hline T.T.Singh & 12168 & 98896 & 111064 & 89.04 & 26.96 \\
\hline Jhang & 21362 & 303099 & 324461 & 93.42 & 29.66 \\
\hline Gujranwala & 15297 & 90617 & 105915 & 85.56 & 13.31 \\
\hline Sialkot & 6447 & 41457 & 47904 & 86.54 & 7.07 \\
\hline Sheikhupura & 15759 & 122817 & 138576 & 88.63 & 17.98 \\
\hline Rechna Doab & 85695 & 852814 & 938509 & 90.87 & 21.01 \\
\hline
\end{tabular}

Note: ${ }^{*}$ A cropping intensity of 1 is assumed ${ }^{* *}$ (NSA + CAI + CWA - GCA) $* 100$. $\mathrm{NSA}+\mathrm{CAI}+\mathrm{CWA}$

$$
\begin{array}{ll}
\text { CA }=\text { Cropped Area } . & \text { CCA }=\text { Currently Cultivated Area } . \\
\text { CI }=\text { Cropping Intensity. } & \text { TICA }=\text { Total Increase in Cropped Area } .
\end{array}
$$


With respect to the GCA in the Rechna Doab, Table 10 provides estimates for the distribution of area under different crops, and shows that on average, about 39 percent of the GCA represent the wheat crop in the Rechna Doab. In the case for the rice crop, the area ranges from 3.06 percent of the GCA in the Faisalabad District to about 36 percent in the Gujranwala District. The estimates show that the area under the cotton crop ranges from 1.46 percent of the GCA in the Sheikhupura District to about 19.31 percent in the Jhang District. The area under sugarcane ranges from 1 percent and 1.67 percent in the Districts Sialkot and Gujranwala to about 17.07 percent of the GCA in the Faisalabad District. On average, the distribution of the area under rice, wheat and sugarcane crops comes to 18.15 percent, 9.68 percent and 8.4 percent, respectively.

When assuming that the farmers' cropping pattern does not change and that the additional croppable area of 0.94 Mha is distributed among the four major crops, Table 11 shows, on average, that about 0.37 Mha will be for wheat cultivation and 0.12 Mha for the rice crop. Also, that the average area for the cotton and the sugarcane crops will be 0.09 and $0.098 \mathrm{Mha}$, respectively, is reflected. The major contribution in terms of the area under all four major crops comes from the Jhang District, followed by the Faisalabad, Sheikhupura and Gujranwala Districts, which are the major contributors in the area for all four crops.

Table 10

Share of Major Crops in Total Cropped Area in Districts of the Rechna Doab (Percentage)

\begin{tabular}{lcccc}
\hline Districts & Wheat & Rice & Cotton & Sugarcane \\
\hline Sialkot* & 40.33 & 34.00 & 0.00 & 1.67 \\
Gujranwala* & 38.67 & 36.33 & 0.00 & 1.00 \\
Sheikhupura & 37.09 & 22.58 & 1.46 & 5.48 \\
Faisalabad & 38.46 & 3.06 & 5.74 & 17.07 \\
T.T.Singh & 37.47 & 7.37 & 12.20 & 13.32 \\
Jhang & 41.71 & 5.58 & 19.31 & 11.86 \\
Rechna Doab & 38.95 & 18.15 & 9.68 & 8.40 \\
\hline
\end{tabular}

Source: Rechna Doab Survey 1995.

* Census of Agriculture 1990.

In consideration of the existing average yields of the four major crops on the farms in the Rechna Doab, Table 12 estimates the potential productivity of the four major crops (wheat, rice, cotton and sugarcane) in the Rechna Doab. Table 12 shows that by increasing the cropping intensity of the existing cultivated areas and by bringing the cultureable uncultivated area under cultivation, the Rechna Doab has the potential to produce 0.947 million metric tons of wheat, 0.281 million metric tons of rice, 0.103 million metric tones of cotton and 4.671 million metric tons of sugarcane. Once again, the major share of the production comes from the Jhang and Faisalabad Districts. 
Table 11

Potential Increment in Area under Major Crops in

Districts of the Rechna Doab (Hectare)

\begin{tabular}{lcccc}
\hline Districts & Wheat & Rice & Cotton & Sugarcane \\
\hline Sialkot & 19321 & 16287 & 0 & 798 \\
Gujranwala & 40953 & 38482 & 0 & 1059 \\
Sheikhupura & 51403 & 31293 & 2017 & 7597 \\
Faisalabad & 80983 & 6448 & 12084 & 35956 \\
Toba Tek Singh & 41615 & 8183 & 13552 & 14789 \\
Jhang & 135327 & 18115 & 62641 & 38489 \\
Rechna Doab & 369603 & 118809 & 90296 & 98688 \\
\hline
\end{tabular}

Table 12

Potential Increment in the Production of Major Crops in the Rechna Doab (Metric Tons)

\begin{tabular}{lcccc}
\hline Districts & Wheat & Rice & Cotton & Sugarcane \\
\hline Sialkot & 39200 & 16700 & 0 & 36000 \\
Gujranwala & 93800 & 49900 & 0 & 43900 \\
Sheikhupura & 151000 & 84000 & 2300 & 439200 \\
Faisalabad & 228400 & 12800 & 12400 & 1772900 \\
T.T.Singh & 111400 & 14500 & 13700 & 701900 \\
Jhang & 344100 & 54400 & 93200 & 2073100 \\
Rechna Doab & 947200 & 281800 & 103100 & 4671900 \\
\hline
\end{tabular}

\section{CONCLUSIONS}

The study attempted to estimate the operational distribution of land holdings in the Rechna Doab across different farm size groups in terms of percentage distribution of holdings and to estimate the total unused cultivable land in the Rechna Doab. After estimating the relationship between the size of the holding and the level of unused cultivable land, this study aimed at analysing the relationship between cropping intensity and the size of holding, and the influence of the level of irrigation on cropping intensity. Also, estimates of the additional productive potential of the four major crops 
(wheat, rice, cotton and sugarcane) grown in the Rechna Doab is analysed. The conclusions that emerged from this study are:

- If a full level of land utilisation (by making improvements in the cropping intensity and by bringing the CWA under cultivation) takes place, the total crop area can be increased by about 0.94 Mha.

- There is a possibility that shares of the cropped area under cultivation for four major crops (wheat, rice, cotton and sugarcane) could be increased, by 0.37 , 0.12, 0.09 and 0.1 Mha, respectively.

- There is a possibility that the production of the four major crops (wheat, rice, cotton and sugarcane) could be increased, by $0.95,0.28,0.10$ and 4.6 million tons, respectively.

- Of this total improvement in cropped area from improvement in cropping intensity and extensive use of land, 34.57 percent will be from the Jhang, 22.44 percent from Faisalabad, 14.77 percent from Sheikhupura, 11.83 percent from Toba Tek Singh, 11.29 percent from Gujranwala and about 5.1 percent from the Sialkot Districts.

- Of the total additional croppable area that comes under cropping through better utilisation of land, 58.75 percent will come from the medium farms, 31.74 percent from large farms and only 9.51 percent from the small farms.

- Within the Rechna Doab, there are wide interdistrict disparities. On average, there can be about 21 percent improvement in land utilisation. In three districts (Jhang, Faisalabad, Toba Tek Singh), the cropping intensity can be improved by more than 75 percent, but there are districts (Sialkot) where only 7.1 percent improvement is possible.

\section{REFERENCES}

Fuss, M., D. McFadden, and Y. Mundlak (1978) Production Economics: A Dual Approach to Theory and Applications. M. Fuss and D. McFadden (eds) Amsterdam: North Holland. 224-225.

IWASRI (1988) Data Release on Various Aspects of Waterlogging and Salinity in the Rechna Doab (Punjab). IWASRI Publication No.1.

Maddala, G. S. (1988) Introduction to Econometrics. London: Macmillan.

Pakistan, Government of (1963) Pakistan Census of Agriculture, 1960. Pakistan Agricultural Census Organisation. Vol. II, West Pakistan, Karachi.

Pakistan, Government of (1975) Pakistan Census of Agriculture, 1972. Pakistan Agricultural Census Organisation. Vol. II, Provincial Reports, Lahore.

Pakistan, Government of (1983) Pakistan Census of Agriculture, 1980. Pakistan Agricultural Census Organisation. Vol. II, Provincial Reports, Lahore.

Pakistan, Government of (1994) Pakistan Census of Agriculture, 1990. Pakistan 
Agricultural Census Organisation. Vol. II, Part 2, Provincial Reports, Lahore.

Pakistan, Government of (1996) Economic Survey, 1995-96. Islamabad: Finance Division, Economic Adviser's Wing.

Ramanathan, R. (1992) Introductory Econometrics with Applications. San Diego, CA: The Dryden Press, University of California—San Diego.

WAPDA (1979) Revised Action Plan for Irrigated Agriculture. Main Report, Vol. 1. Master Planning and Review Division, WAPDA.

WSIP (1990) National Investment Plan. Federal Planning Cell, Lahore. 


\section{Comments}

The importance of agriculture in the process of economic development cannot be underscored. It role as a source of food and fibre and its ability to provide employment—so crucial for poverty alleviation—is well established. Agriculture in Pakistan as in most countries of the world is rapidly moving from resource-based to being science-based. This movement is speeded up in part by the increasing constraints on land and water. Therefore, any paper that attempts to look at the production potential of major crops ${ }^{1}$ given these increasingly binding constraints, is addressing an important need for Pakistan.

The paper under discussion attempts to do so through an interesting use of primary survey data based on an IIMI survey conducted during 1995 coupled with secondary published data from the Agriculture Census Reports for the years 1960, 1972, 1980 and 1990. Its stated intent is to:

- Estimate the operational distribution of land holdings in the Rechna Doab across different farm size groups in terms of the percentage distribution of holdings;

- Determine the total unused cultivable land in the Rechna Doab and to study the relationship between the size of holding and the level of unused cultivable land;

- Study the relationship between cropping intensity and the size of holding, as well as the influence of the level of irrigation on the cropping intensity;

- Determine the level of efficiency in land utilisation for the Rechna Doab, as well as at the District level; and

- Assess the additional potential productivity of four major crops in the Rechna Doab.

The study uses tabular analysis and regression estimates based on a simplistic log-linear functional form to conclude that by making improvements in the cropping intensity and by bringing the existing cultivable (uncultivated) lands under cultivation total cropped area can be increased by about 0.94 Mha; shares of cropped area under the four major crops wheat, rice, cotton and sugarcane could be increased by $0.37,0.12,0.09$ and 0.1 Mha respectively; and, production of these four crops could thus be increased by $0.95,0.28,0.10$ and 4.6 million tons respectively. Of this total improvement the study suggest that 34.57 percent will be from Jhang district,

\footnotetext{
${ }^{1}$ It should be understood that agriculture represents much more than just the crop sector. This is normally lost in studies, such as the one under review, which focus only on the crop sector.
} 
22.44 percent from Faisalabad district, 14.77 percent from Sheikhupura district, 11.83 percent from Toba Tek Singh district, 11.29 percent from Gujranwala district and about 5.1 percent from Sialkot district. Of the total additional crop-able area that would come under cropping through better utilisation of land, 58.75 percent will come from medium farms, 31.74 percent from large farms and only 9.51 percent from small farms. The study finds that within the Rechna area there are wide interdistrict disparities. The study also finds that on the average there can be about 21 percent improvement in land utilisation. While in three districts (Jhang, Faisalabad and Toba Tek Singh) cropping intensity can be improved by more than 75 percent there are districts, such as Sialkot, where only 7.1 percent improvement is possible.

The general thrust of the paper and its eventual objective is useful i.e., to estimate the potential for increased production of four major crops through the full level of utilisation of land. However, the paper, in its present form, does not go far in meeting this objective. I list below a number of weaknesses in the analysis that affect the credibility of the results.

To start with the title of the paper is rather grandiose. While the data on which the study is based relates mainly to the Rechna Doab the title suggests that the paper looks at the potential for all of Pakistan's irrigated agriculture. There are a number of serious problems involved with such generalisation - the most glaring of which is the lack of adequate testing to show that the area under study is indeed representative of all of Pakistan's irrigated agriculture. Only then can such broad generalisations be made. The adequacy of the results as presented to represent even the Rechna Doab is questionable; given that the author's themselves indicate the existence of wide interdistrict disparities. Using data from these districts in a single estimating equation without testing for the similarity of functional forms across districts is liable to have yielded spurious results. Aggregation over place and time assumes similarity of functions. This applies equally to the analysis over time reported in Tables 3 and 4. The $t$-values on the time period dummies do not tell us anything about total shiftsthese would be represented by simultaneous shifts over time in both the intercept and slope.

Moreover, it would have been useful to have tested alternative specifications of the model before deciding on the log-linear form that is chosen. Interestingly, the specification of the models for both cultureable waste area and for cropping intensity are identical (see Equations 1 to 4). The authors do not provide any reasons for doing this in the text. And, the specifications do not take into account lag effects-does previous year's cropping intensity have any effect on this year's cultureable waste area?

The paper does not address fundamental questions. What are the reasons for the present low levels of land utilisation? Are these related to physical constraints such as land quality and the cost of rehabilitation or to structural constraints such as size of holdings etc.? One gets the uneasy feeling that by ignoring these questions the 
authors are assuming that farmers and those connected with agriculture are somehow irrational. This is definitely not so. In order to make any policy recommendations this paper needs to address the reasons for the low levels of land utilisation. Such reasons can easily be highlighted by conducting a comparative analysis of these factors across low and high utilising districts in the sample.

The study makes several simplistic implicit assumptions in computing its crop area and production increase potentials. It assumes, for example, that relative prices and existing levels of crop profitability will remain the same. It also assumes that productivity per hectare will remain the same. These assumptions are not realistic. In fact, by doing so, the authors implicitly assume away the interesting questions; answers to which would have provided credibility to the results and powerful policy prescriptions to the study.

Sohail J. Malik

Innovative Environmental Technologies, Inc., Vienna, VA, U.S.A. 